\section{Effect of temperature on immunocompetence of the blue mussel (Mytilus edulis)}

\author{
Alexandre Beaudry, 1,2 Marlène Fortier,' \\ Stéphane Masson, ${ }^{2}$ Michel Auffret, ${ }^{3}$ \\ Pauline Brousseau, ${ }^{1,4}$ Michel Fournier ${ }^{1,4}$ \\ 'INRS-Institut-Armand-Frappier Research \\ Center, Laval, QC, Canada; ${ }^{2}$ Aquarium du \\ Québec, Québec, QC, Canada; ${ }^{3}$ University \\ of Western Brittany, Brest, France; \\ ${ }^{4}$ ISMER-Université du Québec à \\ Rimouski, QC, Canada
}

\section{Abstract}

The blue mussel is a filter-feeding bivalve commonly used in ecotoxicological monitoring as a sentinel species. Due to climate change and the increase of temperature expected in marine environment, it is important to anticipate potential impacts on this species. The aim of this study was to investigate the immunocompetence of blue mussels acclimated to different temperatures and on the effects of increasing temperatures $\left(5,10\right.$ and $\left.20^{\circ} \mathrm{C}\right)$. Different indices and gonad maturation stages were also determined throughout the experiments. Cell viability, phagocytosis, serum lysozyme activity and cyclooxygenase (COX) activity were evaluated as immune parameters. The cellular immunity was also evaluated after hemocytes exposure to various cadmium concentrations in vitro. The results obtained demonstrate modulation of hemocyte viability and the ability of these cells to phagocytize in absence of contaminants. After the exposure to cadmium, hemocytes showed greater viability at $5^{\circ} \mathrm{C}$ while maintaining a higher phagocytic competence. In addition, the lysozyme activity stayed stable at all tested temperatures, contrary to that of COX, which increased when the mussels were maintained at $20^{\circ} \mathrm{C}$. The evaluation of indices demonstrated no reduction of general conditions during all the experiment despite the increase of temperature and the reduction of the digestive gland weight. Moreover, the lack of food does not affect gonad maturation and the spawning process.

\section{Introduction}

Sentinel species such as bivalves are commonly used in surveys because of their sessile lifestyle, their wide geographical distribution and their food intake through filtering water column. ${ }^{1,2}$ Given their filter feeding ability, mussels like Mytilus edulis can bioaccumulate xeno- biotics, which may affect many physiological systems such as immune system. ${ }^{1,2}$ For this species, one of the main defense mechanism against pathogens is phagocytosis, carried out by hemocytes circulating freely in the hemolymph, ${ }^{2-4}$ which are recognized to be a useful tool for biomonitoring. ${ }^{5}$ Another efficient immune response of bivalves against pathogens is the production of lysozyme. ${ }^{6,7}$ This hemolymph circulating enzyme is secreted following recognition of bacteria or physiological stress. ${ }^{6}$ This enzyme is also known to have digestive function against ingested bacteria, representing both a threat and possible source of food. ${ }^{7,8}$ The lysozyme catalyzes the hydrolysis of muramic acid of bacteria glycosidic bonds. ${ }^{9}$ Moreover, a stressful condition can modulate the production of prostaglandins or other inflammatory mediators. ${ }^{10}$ The inflammation level can be assessed by measuring the degradation of the arachidonic acid by the cyclooxygenase (COX) activity ${ }^{10}$ known as a rate-limiting enzyme of production of prostaglandins. ${ }^{11}$ An increase of pro-inflammatory precursors by COX activity aims to sustain the immune response $^{12}$ leading to hemocyte bactericidal activity. ${ }^{6}$ Furthermore, the COX activity increases progressively during the final maturation of gonads to reach the highest level during the spawning process. ${ }^{13}$ To improve our comprehension of bivalve's response in a contaminated habitat, it is crucial to understand how the mussels modulate their immunity to face natural challenges such as temperature variations.

Several studies were performed to investigate the effects of environmental factors such as salinity, ${ }^{1}$ temperature, ${ }^{5,14-16}$ hydrodynamic factors, ${ }^{5,14}$ phytoplankton concentration and food intake $\mathrm{e}^{5,14,17}$ on different physiological aspect of $M$. edulis. ${ }^{1,5,14-17}$ However, the influence of temperature on bivalve immunity in controlled conditions have been investigated only on a limited number of species including Chamelea gallina, ${ }^{18}$ Mytilus galloprovincialis $^{3,19,20}$ and Crassostrea gigas. ${ }^{4,21}$ The influence of temperature on $M$. edulis was evaluated but only in the context of a stress on stress protocol including a pathogen and a xenobiotic. ${ }^{22,23}$

Therefore, this paper aims to determine how $M$. edulis can modulate its immune system when exposed to different temperatures in vivo $\left(5,10\right.$ and $\left.20^{\circ} \mathrm{C}\right)$ and combined to an in vitro cadmium exposure.

\section{Materials and Methods}

\section{Animals}

M. edulis were bought from a mussel farm, located in Québec (La moule du large, Îles de la Madeleine, QC, Canada, $47^{\circ} 23$ N 61 $52 \mathrm{~W}$ ). For each part of the experiment, 30 mussels were sampled and analyzed individually to
Correspondence: Michel Fournier, ISMERUniversité du Québec à Rimouski, 310 Allée des Ursulines, Rimouski, QC G5L 3A1, Canada. Tel.: +1.418.724.1650 - Fax: +1.418.721.3326.

E-mail:michel_fournier@uqar.ca

Key words: Mytilus edulis; mussels; bivalves; temperature; immunology.

Acknowledgements: this study was supported by the Canada Research Chair in Environmental Immunotoxicology (Dr. M. Fournier), the Aquarium du Québec and the NSERC. The analysis was conducted at INRS-Institut ArmandFrappier in the environmental immunotoxicology laboratory (MF) and at the St. Lawrence Center of Environment Canada (Dr. F. Gagné). We also would like to thank Ms Chantale André (Environment Canada) for her great technical assistance.

Contributions: AB, lead author, research, study design, specimens and statistical analysis; SM, system installation and maintenance; MF, MA, PB and MF, manuscript correction and revision.

Conflict of interest: the authors declare no potential conflict of interest.

Received for publication: 16 March 2016.

Revision received: 10 May 2016.

Accepted for publication: 7 July 2016 .

This work is licensed under a Creative Commons Attribution NonCommercial 4.0 License (CC BYNC 4.0).

(C) Copyright A. Beaudry et al., 2016

Licensee PAGEPress, Italy

Journal of Xenobiotics 2016; 6:5889

doi:10.4081/xeno.2016.5889

assess their general condition through indices and immunological responses including cellularity, viability of hemocytes and the phagocytosis activity.

\section{Experimental design}

The mussels were bought in December, when water temperature was at $5^{\circ} \mathrm{C}$ and were kept in artificial salt water tank $(4 \times 480 \mathrm{~L}$ with a life-support system) at the field conditions $\left(5^{\circ} \mathrm{C}\right.$, Instant Ocean $28 \mathrm{psu}$ and $\left.\mathrm{pH} 8.0\right)$ without being fed. After 2 weeks of acclimatization (T0), the temperature was increased by $1^{\circ} \mathrm{C}$ each day to reach $10^{\circ} \mathrm{C}$ after 7 days (T7) then, maintained in this experimental phase for 28 days (T35). Subsequently, the temperature was increased again to reach $20^{\circ} \mathrm{C}$ by raising it by $2^{\circ} \mathrm{C}$ per day during a week (T42). The mussels were kept again at $20^{\circ} \mathrm{C}$ for another 28 days (T70). At the end of each experimental phase (acclimatization or raise of temperature), 30 mussels were sacrificed to perform the analysis. 


\section{Histological sex identification}

The sex and gametogenic stage were determined histologically for each mussel using a section $\left(0.5 \times 0.5 \mathrm{~cm}^{2}\right)$ of the central part of the gonad. The mantle section was fixed in Bouin solution, then dehydrated and embedded in paraffin. Slices of $5 \mu \mathrm{m}$ thick were mounted on microscope slide and stained with hematoxylin/eosin. Maturation stage was determined and used to calculate a distinct maturity index for females and males. ${ }^{5,24}$

\section{Index analysis}

Three indices were evaluated: the hepatosomatic index (DGI), the gonado-somatic index (GSI) and the condition index (CI) $(n=30)$. DGI was calculated based on the digestive gland mass on the total soft wet tissue mass, ${ }^{17} \mathrm{GSI}$ using the gonad mass on the total mass of soft wet tissue ${ }^{25}$ and CI was calculated by dividing the weight of wet tissue by the total mass. ${ }^{17,25}$

\section{Viability, cellularity and phagocytosis}

Before dissection of mussels for index analysis, hemolymph was extracted from the adductor muscle using a $3.0 \mathrm{~mL}$ syringe and a $23 \mathrm{~g}$ needle $(\mathrm{n}=30)$. The cellularity and viability were determined by adding propidium iodide (PI $1 \mu \mathrm{g} / \mathrm{mL}$ ) to the hemolymph and analyzed by flow cytometry using a FacsCalibur (Becton Dickinson, San Jose, CA, USA). The phagocytosis was evaluated by mixing $1.72 \mu \mathrm{m}$ yellow-green latex FluoSpheres (Molecular Probes Inc., Eugene, OR, USA) with a volume of $500 \mu \mathrm{L}$ of hemolymph containing 100,000 non-exposed viable cells. Six to eight mussels were also selected for a $3 \mathrm{~h}$ in vitro exposure to cadmium chloride $\left(\mathrm{CdCl}_{2}\right)$ at different concentrations ranging from 0 to $10^{-3} \mathrm{~m}$ diluted in artificial salt water (28 psu, Instant Ocean). The ratio hemocytes:beads was kept at 1:100. After 18 hours of incubation, in the dark at $20^{\circ} \mathrm{C}$, the mixture was delicately transferred on a $3 \%$ bovine serum albumin gradient prepared in Roswell Park Memorial Institute-1640 supplemented with $3 \%$ of sea salt. The tubes were centrifuged at $125 \mathrm{~g}$ for $8 \mathrm{~min}$ to remove free beads. Then, supernatant was removed and hemocytes resuspended in artificial sea salt solution containing $0.5 \%$ of paraformaldehyde and $0.2 \%$ of sodium azide. The phagocytic capacity ( 1 bead and more) and efficacy ( 3 beads and more) were measured by flow cytometry. A total of 5000 events were recorded for each hemolymph sample. Data collection and analysis were performed with Cell Quest Pro software.

\section{Lysozyme activity}

The lysozyme activity was measured in duplicates for each mussel $(n=30)$ in $100 \mu \mathrm{L}$ of cell free hemolymph (centrifuged for $10 \mathrm{~min}$ at $1000 \mathrm{~g}$ ) with $100 \mu \mathrm{L}$ of Micrococcus lysodeikticus prepared at $0.4 \mathrm{mg} / \mathrm{mL}$ in a $100 \mathrm{~mm}$ phosphate buffer at pH 6.2. Absorbance was immediately measured at $450 \mathrm{~nm}$ with a microplate reader Synergy4 (Software: Gen5 V:2.05) and then every minute after the initial reading for a total of $5 \mathrm{~min}$. The decrease in absorbance at $450 \mathrm{~nm} / \mathrm{min}$ was than calculated like previously described by Lee and Yang (2002). ${ }^{9} \mathrm{~A}$ unit of lysozyme activity is defined as the quantity of enzyme, which causes a decrease of 0.001 per

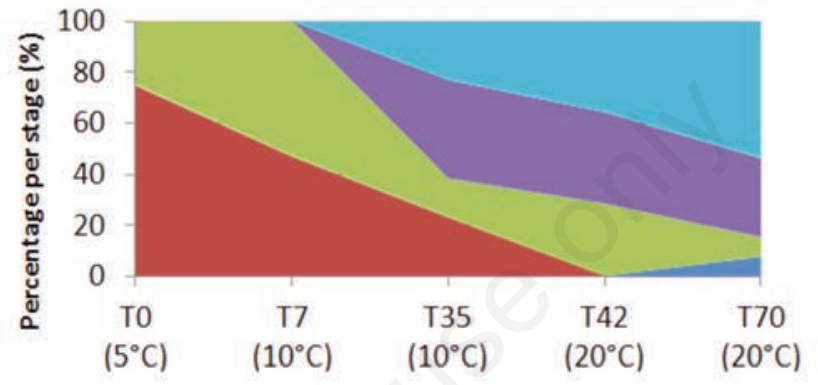

E5 (post-spawn) -F4 (mature) ma $\mathrm{F} 3$ (ripe)

F2 (development) F1 (indifferent)

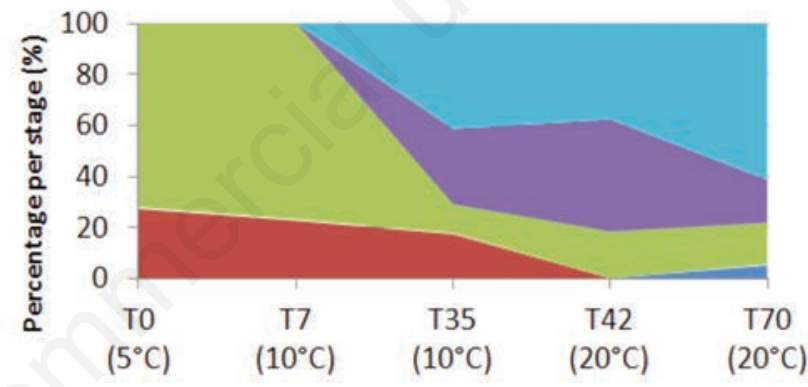

M5 (post-spawn) M4 (mature) 들 (ripe) - $\mathrm{M} 2$ (development) - M1 (indifferent)

Figure 1. Maturation stage (\%) of Mytilus edulis for female and male during the experiment following an increase of temperatures $(n=30 /$ experimental phase, $P<0.05)$ [Stage 1 (indifferent) $=\square$; Stage 2 (development) $=\square$; Stage 3 (ripe) $=\square$; Stage 4 (mature) $=\square ;$ Stage 5 (post-spawn) = $\square$ ].

A

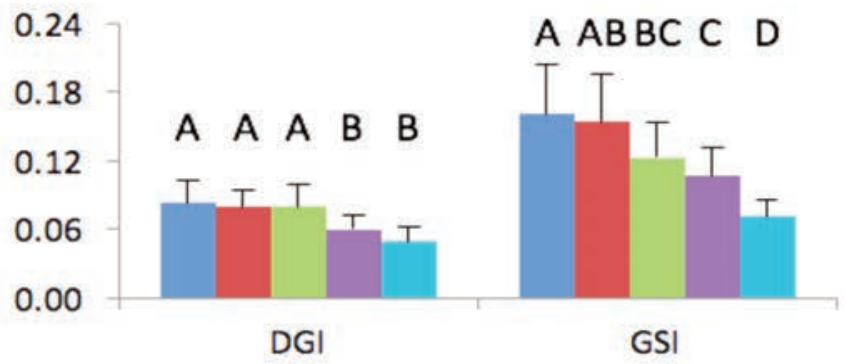

B

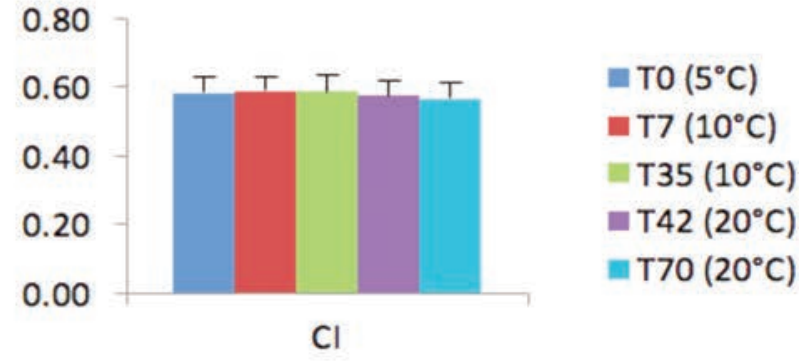

Figure 2. A) Variation of relative weight of digestive gland (DGI) and gonads on total soft tissue (GSI); and B) condition index (CI) during the experiment $(n=30 /$ experimental phase, $P<0.05)$. 
minute in absorbance at $\mathrm{pH} 6.2$ at $25^{\circ} \mathrm{C}$. All lysozyme and protein measurements were done in 96-well plates in duplicates. Chicken egg lysozyme (Sigma, ON, Canada) was used for calibration and the results expressed were standardized by the protein concentration in hemolymph using the protein dye binding method.

\section{Inflammation level}

COX activity was measured in duplicates as described by Fujimoto and colleagues (2002), using the oxidation of 2',7'-dichlorofluorescin diacetate in the presence of arachidonate. ${ }^{26}$ Briefly, 200,000 hemocytes were resuspended in $150 \mu \mathrm{L}$ of pre-diluted PBS (1/4) and $25 \mu \mathrm{L}$ of this cell suspension was mixed to $150 \mu \mathrm{L}$ of reaction media. The reaction media was composed of $50 \mathrm{mmol} / \mathrm{L}$ Tris- $\mathrm{HCl}$, pH 8.0, containing $0.05 \%$ Tween-20, $50 \mu \mathrm{mol} / \mathrm{L}$ arachidonic acid, $2 \mu \mathrm{mol} / \mathrm{L}$ dichlorofluorescein and 0.1 $\mu \mathrm{g} / \mathrm{mL}$ horseradish peroxidase. The fluorescence readings were taken at $0,3,6$ and 12 min at $25^{\circ} \mathrm{C}$ using $485 \mathrm{~nm}$ excitation and 530 $\mathrm{nm}$ emission wavelength (Synergy4, Gen5

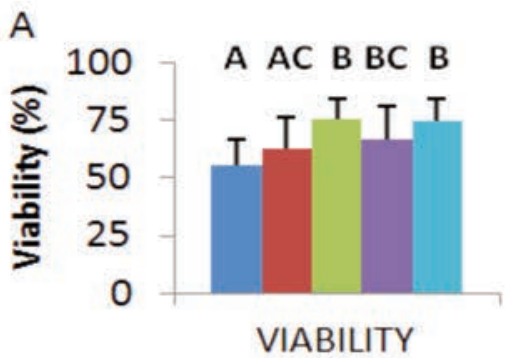

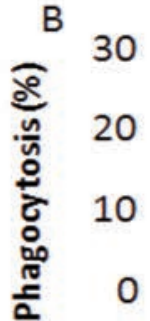

A B B A A

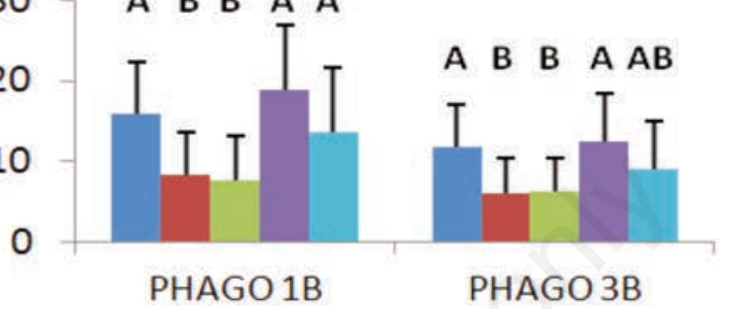

TO $\left(5^{\circ} \mathrm{C}\right)$

- $T 7\left(10^{\circ} \mathrm{C}\right)$

T35 $\left(10^{\circ} \mathrm{C}\right)$

- T42 $\left(20^{\circ} \mathrm{C}\right)$

든 $\left(20^{\circ} \mathrm{C}\right)$

Figure 3. A) Hemocytes viability; B) phagocytic capacity (1 bead and more) and efficacy (3 beads and more) of Mytilus edulis expose to different temperature $(\mathrm{n}=30 /$ experimental phase, $\mathrm{P}<0.05)$.
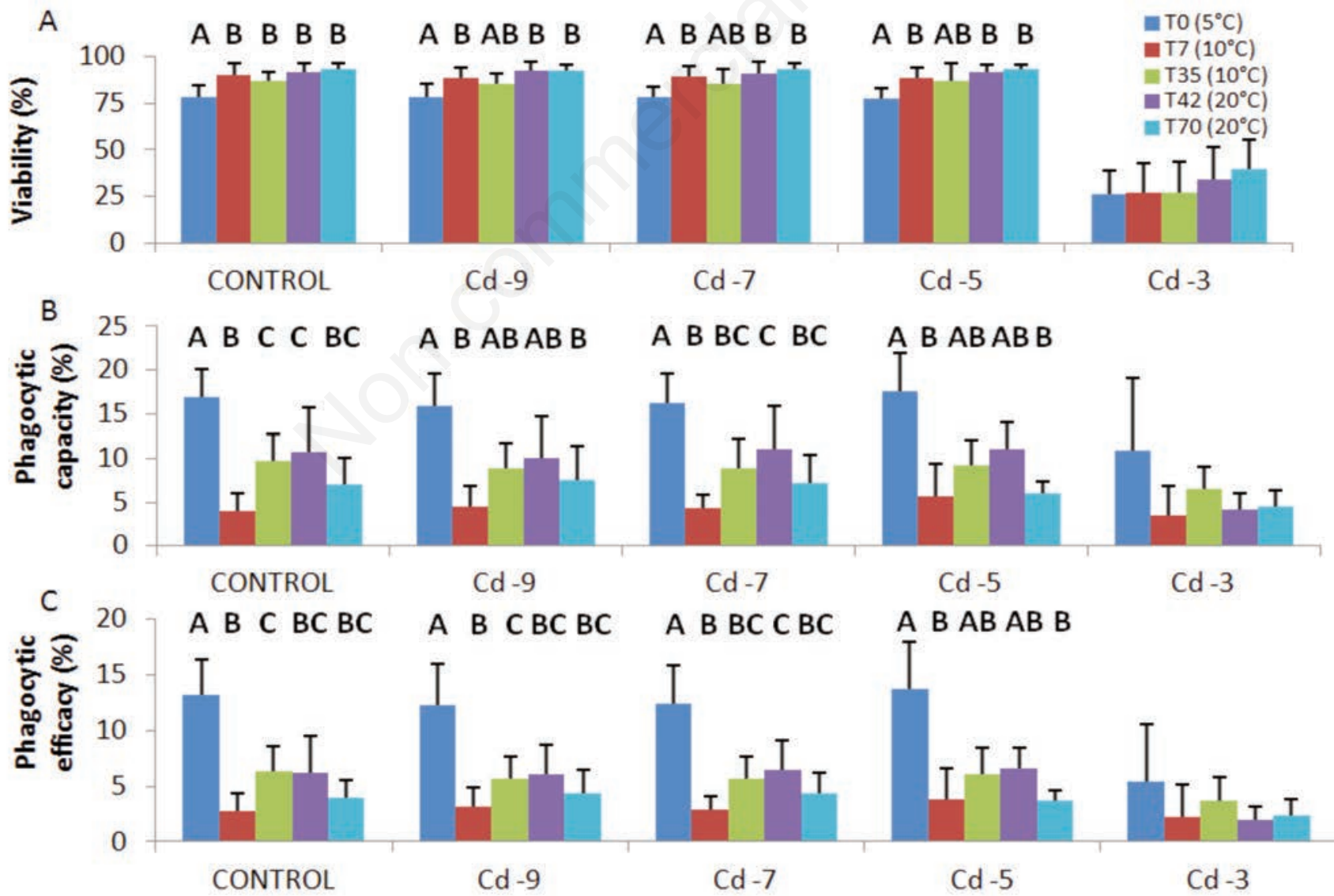

Figure 4. A) Hemocytes viability; B) phagocytic capacity (1 bead and more); and C) efficacy ( 3 beads and more) of Mytilus edulis exposed to different temperatures. Hemocytes were challenged in vitro with cadmium chloride at concentrations ranging from 0 to $10^{-3} \mathrm{M}(\mathrm{n}=6-8$ mussels/experimental phase, $\mathrm{P}<0.05)$. 
V2.05). The data were expressed in relative fluorescence units/min/mg of protein $(n=30)$.

\section{Statistical analysis}

One-way ANOVA followed by Tukey's test for pairwise comparisons were applied between experimental phases. Statistical analyses were performed using SigmaStat (version 3.5). For all statistical tests, we have used individual mussels as replicates. Significance was set at $\mathrm{P}<0.05$.

\section{Results}

\section{Gender difference and sexual maturity}

No significant differences were observed between genders for all cellular and molecular analyses performed during the experiment. For sexual maturation of $M$. edulis, the results in Figure 1 demonstrate a clear progression in the gonads development of both sexes. At the beginning of the experiment (T0), the male gametes were more mature than female until T35, when the sexual maturation of females and males showed no more differences.

\section{Indices}

All the results for the indices are presented in Figure 2. For DGI, the digestive gland weight was stable for the first 35 days corresponding to about $8 \%$ of the soft wet tissue. After 42 days, the weight of this organ declined significantly representing only $6 \%$ of the tissue mass. After 70 days, the DGI decreased at 5\%, which was not enough to be significantly different of results obtained at $\mathrm{T} 42$ but still significantly smaller for T0 to T35 days of experiment.

For GSI, the gonad weights reach their maximum at $\mathrm{T} 0$ and $\mathrm{T} 7$, representing 16 and $15 \%$ of the tissue mass respectively. After 28 days at $10^{\circ} \mathrm{C}$ (T35), the GSI value decreased significantly until the end, reaching $12 \%$ at T35, $11 \%$ at T42 and finally 7\% (T70) of the tissue mass.

For the CI, no significant changes were observed during the experiment.

\section{Viability and phagocytosis}

For viability and phagocytosis, the results are presented in Figure 3 . At $5^{\circ} \mathrm{C}$, hemocyte viability was at its lower value reaching only $55.9 \%$ of viable cells. By increasing the temperature, the viability increased but not significantly at T7 (62.8\%) but became significantly higher after 28 days at $10^{\circ} \mathrm{C}$ (T35) to attain $75.5 \%$. During the temperature modification up to $20^{\circ} \mathrm{C}$ (T42), the viability slightly went down but not significantly and returned to the highest value after being kept in stable condition for another 28 days (T70).

The phagocytic activity of hemocytes reached an optimal value at $5^{\circ} \mathrm{C}(\mathrm{T} 0)$ and at $20^{\circ} \mathrm{C}$ (T42 and T70), with the exception of the phagocytic efficacy at T70, showing no significant differences. At $10^{\circ} \mathrm{C}$ ( $\mathrm{T} 7$ and $\mathrm{T} 35$ ), the phagocytic capacity and efficacy were stable and significantly lower.

\section{Cadmium exposure: viability and phagocytosis}

For cadmium exposures, the results are presented in Figure 4. For all $\mathrm{CdCl}_{2}$ concentrations, except for $10^{-3} \mathrm{M}$ where the hemocytes viability decreased significantly, the percentage of viable cells was significantly lower when mussels were maintained at $5^{\circ} \mathrm{C}$, except at T35. The highest phagocytic activity was obtained when the mussels were kept at $5^{\circ} \mathrm{C}$ (T0) and the lowest values after the increased of temperature to $10^{\circ} \mathrm{C}$ (T7). After 28 days at $10^{\circ} \mathrm{C}$ (T35), the phagocytic activity reached an intermediate value which remained relatively stable until the next time (T42). Then, there were no other changes for the remaining of the experiment (T70).

\section{Lysozyme and cyclooxygenase activities}

For the lysozyme and the cyclooxygenase activity, the results are showed in Figure $5 \mathrm{~A}$ and $B$ respectively. During all the experiment, there was no significant modulation of the lysozyme activity by temperature.

For the COX activity, the results showed an increase after being kept at the same temperature for a month $\left(\mathrm{T} 35=10^{\circ} \mathrm{C}\right.$ and $\mathrm{T} 70=20^{\circ} \mathrm{C}$ ) with a significant difference only at T70.
During the temperature modifications (T7 and T42), there is no significant difference with the control (T0).

\section{Discussion}

During eco-toxicological field studies, the immunomodulation analysis remains a complex issue because of the confounding factors such as temperature, salinity, etc. All these factors can influence the capacity of an organism to deal with a pathogen, a xenobiotic's mixture or combined stress. ${ }^{27}$ With this research, we wanted to understand how $M$. edulis can react and adapt its immune system to a range of temperatures and following by an exposure to $\mathrm{CdCl}_{2}$ in a stress to stress study. This type of study was conducted on bivalves, with various experimental designs, but not for M. edulis on a long-term experiment in controlled conditions. Indeed, it is already well established that temperature can affect bivalve growth ${ }^{5,14}$ and it is in direct relation with the food availability and reproduction cycle. ${ }^{5,14-16}$ This relationship with the spawning period was clearly observed during our experiment and can be observed by the important decreased in the GSI (Figure 2). Indeed, after being maintained for 28 days at $10^{\circ} \mathrm{C}$ (T35) without food, the mussels initiate their spawning and pursue it until the end. Moreover, it has been shown that DGI (energy reserved organ) can change in stressful condi-
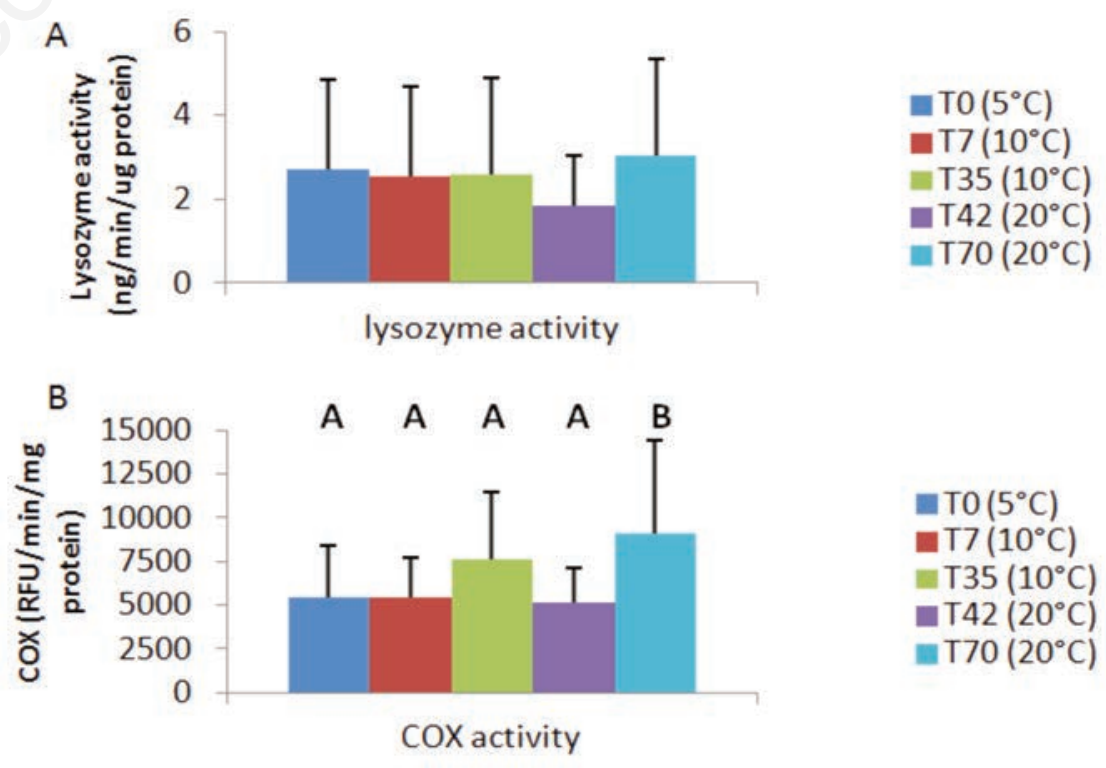

Figure 5. A) Lysozyme activity in cell-free hemolymph; B) and cyclooxygenase (COX) activity on hemocytes of Mytilus edulis exposed to different temperatures ( $\mathrm{n}=30$ /experimental phase, $\mathrm{P}<\mathbf{0 . 0 5}$ ). 
tion and during high metabolic demand such as gametogenesis. ${ }^{16,17}$ We can see in our results a significant decrease of the DGI seven days after spawn beginning, which also concord with the first sacrifice at $20^{\circ} \mathrm{C}$ (T42). The histological analysis allowed us to confirm the clear progression of the maturity index of both sexes, which confirms the increase in energetic demand for gametogenesis. Despite the decrease in the DGI and GSI, the general condition (CI) of our blue mussels did not change.

The variation of temperature can also affect the bivalve immunity in different ways according to the species. Indeed, Matozzo and colleagues (2012) have shown that this confounding factor can modify the hemocyte count and the lysozyme activity on $C$. gallina and $M$. galloprovincialis. ${ }^{3}$ However, Li and colleagues (2008) did not observe this effect on lysozyme after a thermal choc at 5 and $30^{\circ} \mathrm{C} .{ }^{20}$ Moreover, it had been noticed that high temperature can decrease the time of hemocytes spreading in M. galloprovincialis, ${ }^{19}$ the number of viable hemocytes in $C$. gigas ${ }^{21}$ and the ability of $C$. gallina hemocytes to phagocyte yeast particles. ${ }^{4,18}$ All these variations in bivalve's species showed the importance of understanding also how $M$. edulis immunity can vary at different temperatures. For $M$. edulis, our results showed that the hemocyte viability is lower at $5^{\circ} \mathrm{C}$ with and without $\mathrm{CdCl}_{2}$ exposure. This reduced viability value may be due to an adaptation to cold temperatures to avoid consuming too much energy (reduced standard metabolic rate). ${ }^{28}$ Despite this result, the phagocytic capacity and efficacy of the hemocytes is clearly higher, especially when exposed to $\mathrm{CdCl}_{2}$ (Figures 3 and 4). In addition, the risk of infection is less important in cold water given that the clearance rate of mussels is higher than the pathogen proliferation. ${ }^{22}$ Moreover, Fisher and Tamplin (1988) showed that temperature also influence the hemocyte locomotion. ${ }^{29}$ However, the mussel hemocytes are still ready to be challenged as shown in our results following the $\mathrm{CdCl}_{2}$ exposure (Figure 4). After reaching $10^{\circ} \mathrm{C}$ (T7), the hemocytes viability increased by $7 \%$ and became superior by almost $20 \%$ after 28 days (T35) compared to T0. On the other hand, the phagocytosis activity decreased to his lowest level (T7 and T35), but when exposed to $\mathrm{CdCl}_{2}$ the hemocytes from the acclimated mussels at $10^{\circ} \mathrm{C}$ (T35) have better engulfment of beads than after increasing the temperature (Figures 3 and 4). The mussels still seem to have the ability to adapt their immunity by modulating upward the number of viable hemocytes (results not shown), despite a reduction of phagocytosis. The low result obtained can be explained by the experimental design that limits pathogen proliferation and immunological stimulation.

After T35, temperature was increased to reach $20^{\circ} \mathrm{C}$ (T42) and there was a variation in
M. edulis immunity. However, the spawning effect on immunity needs to be considered. Indeed, Lemaire and colleagues (2006) have noticed a significant diminution of the phagocytosis during the spawning period which was also confirmed by Fraser and colleagues (2013). ${ }^{3,30}$ However, we did not observe this decrease of phagocytosis after the beginning of the spawn but a significant increase (T42) compared to the previous sacrifice (T35). This divergence in our results in Figure 3 may possibly be explained by: i) an increase in bacterial proliferation in the tanks which challenged the mussel's hemocytes which have reacted with a stronger phagocytic response; or ii) a recovery of the phagocytic ability like demonstrate on the Pacific oyster ${ }^{20}$ and mentioned by Fraser and colleagues (2013) for M. edulis. ${ }^{30}$ Indeed after 28 days at $20^{\circ} \mathrm{C}$ (T70), with a continuous spawning since T35, the phagocytic activities probably begin to decline due to the mussels filtering the water in the tanks to be almost cleared of gametes and bacteria's and decreased the pressure on the immune system (Figure 3). We also observed the same pattern following the cadmium exposure (Figure 4). On the other side, the lysozyme activity is very stable throughout the experiment despite the temperature variations. Similar results were obtained by Li and colleagues (2008) for Mytilus galloprovincialis, ${ }^{20}$ and Nilsen and colleagues (1999) for Chlamys islandica who observed that this enzyme was active in cold temperatures and kept a stable activity when heated. ${ }^{7,8} \mathrm{On}$ the other side, the modulation of COX activity observed in the Figure $5 \mathrm{~B}$ may be caused by the spawning process. In fact, the COX activity increased non-significantly after four weeks at $10^{\circ} \mathrm{C}$ (T35) when this process begin. Then, a significant higher level was reached at $\mathrm{T} 70$ after a month at $20^{\circ} \mathrm{C}$ during the principal spawning moment. This result can also be observed with the variation of GSI (Figure 2) and by progression of the maturity index (Figure 1). The evaluation of the maturity index (Figure 1) allows us to observe a clear progression in the gamete development of mussels and the percentage of them who have already spawn. In fact, an increase in the COX activity to assist the spawning process has already been observed and confirmed in other experiment. ${ }^{13}$ This increase of the COX activity in the hemocytes might be caused to help the recovery of the phagocytic activity like previously reported. All immunological parameters were analyzed by gender, but no significant differences between males and females were observed (results not shown).

With this experiment, we have demonstrated that M. edulis can adjust its cellular immunity by modulating their number of viable hemocytes, their viability and their phagocytic capacity and efficacy. However, we observed that mussels kept at $5^{\circ} \mathrm{C}$ have a better ability to face a stress on stress challenge such as cadmium exposure. We have also shown that the lysozyme activity stays stable at all temperatures. Moreover, we have confirmed that the spawning is influenced by water temperature and assisted by an increase of COX activity in M. edulis. Finally, all analysis was performed between sexes and no significant differences were found. This study also consolidates the importance of evaluating the impact of confounding factors in field studies.

\section{Research highlights}

- Mytilus edulis were maintained in tanks without food to assess the immuno-modulation caused by temperature $\left(5^{\circ} \mathrm{C}, 10^{\circ} \mathrm{C}\right.$ and $\left.20^{\circ} \mathrm{C}\right)$.

- In vivo temperature exposition modulated the hemocytes viability and phagocytosis of Mytilus edulis.

Hemocytes exposed in vitro to various cadmium concentrations showed a greater viability and phagocytosis when they are exposed the lower temperature $\left(5^{\circ} \mathrm{C}\right)$.

- The enzymatic activity of lysozymes stayed stable at all temperature, while the cyclooxygenase activity increased when mussels were maintained at $20^{\circ} \mathrm{C}$.

\section{References}

1. Bussell JA, Gidman EA, Causton DR, Bussella JA, Gidmanb EA, Caustonb DR, et al. Changes in the immune response and metabolic fingerprint of the mussel, Mytilus edulis (Linnaeus) in response to lowered salinity and physical stress. J Exp Mar Biol Ecol 2008;358:78-85.

2. Alix G, Beaudry A, Brousseau-Fournier C, Fortier M, Auffret M, Fournier M, et al. Increase sensitivity to metals of hemocytes obtained from Mya arenaria collected at different distances from the shore. $\mathrm{J}$ Xenobiotics 2013;3:29-30.

3. Matozzo V, Chinellato A, Munari M, Finos L, Bressan M, Marin MG. First evidence of immunomodulation in bivalves under seawater acidification and increased temperature. Plos One 2012;7:1-14.

4. Mosca F, Narcisi V, Calzetta A, Gioia L, Finoia MG, Latini M, et al. Effects of high temperature and exposure to air on mussel (Mytilus galloprovincialis, Lmk 1819) hemocyte phagocytosis: modulation of spreading and oxidative response. Tissue Cell 2013;45:198.203.

5. Lemaire N, Pellerin J, Fournier M, Giraultc L, Tamigneauxc E, Cartiera $\mathrm{S}$, et al. Seasonal variations of physiological parameters in the blue mussel Mytilus spp. from farm sites of eastern Quebec. Aquaculture 2006;261:729-51. 
6. Gust M, Gélinas M, Fortier M, Fournier M, Gagné F. In vitro immunotoxicity of environmentally representative antibiotics to the freshwater mussel Elliptio complanata. Environ Pollut 2012;169:50-8.

7. Mydlarz LD, Jones LE, Harvell CD. Innate immunity, environmental drivers, and disease ecology of marine and freshwater invertebrates. Annu Rev Ecol Syst 2006;37:251-88.

8. Nilsen IW, Overbø K, Sandsdalen E, Sandaker E, Sletten K, Myrnes B. Protein purification and gene isolation of chlamysin, a cold-active lysozyme-like enzyme with antibacterial activity. FEBS Lett 1999;464:153-8.

9. Lee YC, Yang D. Determination of lysosome activities in a microplate format. Anal Biochem 2002;310:223-4.

10. Gagné F, Douville M, Fortier M, Fournier $M$. Effects of a municipal effluent on freshwater mussel Elliptio complanata following challenge with Vibrio anguillarum. J Environ Sci 2015;37:91-9.

11. Rowley AF, Vogan CL, Taylor GW, Clare AS. Prostaglandins in non-insectan invertebrates: recent insights and unsolved problems. J Exp Biol 2005;208:3-14.

12. Auffret M. Bivalves as models for marine immunotoxicology. In: Tryphonas $\mathrm{H}$, Fournier M, Blakley BR, Smits JEG, Brousseau P, eds. Investigative immunotoxicology. New York, NY: Taylor and Francis; 2005. pp 29-48.

13. Gagné F, Blaise C, Pellerin J, André C. Neuroendocrine disruption in Mya arenaria clams during gametogenesis at sites under pollution stress. Mar Environ Res 2007;64:87-107.

14. Seed R. Ecology. In: Bayne BL ed. Marine mussels: their ecology and physiology. New York, NY: Cambridge University
Press; 1976. pp 13-66.

15. Maugmyint U, Tyler PA. Effects of temperature, nutritive and metal stressors on the reproductive biology of Mytilus edulis. Mar Biol 1982;67:209-23.

16. Thompson RJ. The reproductive cycle and physiological ecology of the mussel Mytilus edulis in a subarctic, non-estuarine environment. Mar Biol 1984;79:277-88.

17. Cartier S, Pellerin J, Fournier M, Tamigneauxc E, Giraultc L, Lemairea N. Use of an index based on the mussel (Mytilus edulis and Mytilus trossulus) digestive gland weight to assess the nutritional quality of mussel farm sites. Aquaculture 2004;241:633-54.

18. Monari M, Matozzo V, Foschi J, Cattani 0, Serrazanetti GP, Marin MG. Effects of high temperatures on functional responses of haemocytes in the clam Chamelea gallina. Fish Shellfish Immunol 2007;22:98-114.

19. Carballal MJ, Lopez C, Azevedo C, Villalba A. In vitro study of phagocytic ability of Mytilus galloprovincialis hemocytes. Fish Shellfish Immunol 1997;7:403-16.

20. Li H, Parisi MG, Toubiana M, Cammarata M, Roch P. Lysozyme gene expression and hemocyte behavious in the Mediterranean mussel, Mytilus galloprovincialis, after injection of various bacteria or temperature stresses. Fish Shellfish Immunol 2008;25:143-52.

21. Gagnaire B, Frouin H, Moreau K, ThomasGuyon H, Renault T. Effects of temperature and salinity on haemocyte activities of the Pacific oyster Crassostrea gigas (Thunberg). Fish Shellfish Immunol 2006; 20:536-47.

22. Hernroth B. The influence of temperature and dose on antibacterial peptide response against lipopolysaccharide in the blue mussel, Mytilus edulis. Fish Shellfish
Immunol 2003;14:25-37.

23. Parry HE, Pipe RK. Interactive effects of temperature and copper on immunocompetence and disease susceptibility in mussels (Mytilus edulis). Aquat Tox 2004;69:311-25.

24. Ruiz Y, Suarez P, Alonso A, Longo E, Villaverde A, San Juan F. Environmental quality of mussel farms in Vigo estuary: pollution by PAHs, origin and effects on reproduction. Environ Pollut 2011;159:250-65.

25. Pellerin J, Fournier M, Gauthier-Clerc S, Blaise C, Garnerot F, Amiard JC, Gagné F. Qu'en est-il de l'état de santé des myes au Saguenay? Un bilan d'études sur plus d'une décennie. Rev Sci Eau 2009;22:271-89.

26. Fujimoto Y, Sakuma S, Inoue T, Uno E, Fujita T. The endocrine disruptor nonylphenol preferentially blocks cyclooxygenase-1. Life Sci 2002;70:2209-14.

27. Gagné F, Blaise C, Pellerin J, Fournier M, Durand MJ, Talbot A. Relationships between intertidal clam population and health status of the soft-shell clam Mya arenaria in the St. Lawrence Estuary and Saguenay Fjord (Québec, Canada). Environ Int 2008;34:30-43.

28. Sokolova IM, Lannig G. Interactive effects of metal pollution and temperature on metabolism in aquatic ectotherms: implications of global climate change. Clim Res 2008;37:181-201.

29. Fisher SW, Tamplin M. Environmental influence on activities and foreign-particles binding by hemocytes of American oysters, Crassostrea virginica. Can J Fish Aquat Sci 1988;45:1309-15.

30. Fraser M, Rault PH, Fortier M, Fortier M, André C, Brousseau P, et al. Decrease in phagocytosis capacity of hemocyte during spawning in Mytilus edulis: a pilot study. $\mathrm{J}$ Xenobiotics 2013;3:31-3. 